\title{
Corrosion Effects on the Strength Properties of Steel Fibre Reinforced Concrete Containing Slag and Corrosion Inhibitor
}

\author{
Sivakumar Anandan, Sounthararajan Vallarasu Manoharan, \\ and Thirumurugan Sengottian
}

VIT University, Vellore, Tamil Nadu 632 014, India

Correspondence should be addressed to Sivakumar Anandan; sivakumara@vit.ac.in

Received 30 June 2014; Revised 24 October 2014; Accepted 25 October 2014; Published 17 November 2014

Academic Editor: Ramazan Solmaz

Copyright (C) 2014 Sivakumar Anandan et al. This is an open access article distributed under the Creative Commons Attribution License, which permits unrestricted use, distribution, and reproduction in any medium, provided the original work is properly cited.

Corrosion in steel can be detrimental in any steel rebar reinforced concrete as well as in the case of steel fibre reinforced concrete. The process of corrosion occurring in steel fibre incorporated concrete subjected to corrosive environment was systematically evaluated in this study. Concrete specimens were prepared with steel fibre inclusions at $1.5 \% V_{f}$ (volume fraction) of concrete and were added in slag based concrete (containing manufactured sand) and replaced with cement at $20 \%, 40 \%$, and $60 \%$ of total binder. Accelerated corrosion studies were carried out using alternate wetting and drying cycle accompanied with initial stress at $40 \%$ and $60 \%$ of ultimate stress. Concrete specimens were then immersed in chloride-free water and sodium chloride solution (3.5\%) after subjecting to initial stress. The alternate wetting and drying process of different concrete mixes was continued for longer exposure (6 months). Later, the strength degradation during the accelerated corrosion process was then assessed in compressive and flexural tests. Test results indicated that the strength degradation was marginal in the case of steel fibre reinforced concrete containing higher slag content and for the concretes containing corrosion inhibitors. The maximum strength reduction was noticed in the case of plain concrete containing steel fibres and, with the slag addition, a considerable reduction in corrosion potential was noticed. Also, with the increase in slag replacement up to $60 \%$, a significant increase in strength was noticed in flexural test. Experimental test results also showed that the corrosion process in steel fibre reinforced concrete can be controlled with the incorporation of corrosion inhibitors in cementitious system.

\section{Introduction}

The process of corrosion in reinforced concrete elements requires more focus in the present construction practice due to the reduction in service life performance. Steel inclusion in concrete elements cannot be avoided as a result of corrosion process and necessitates more careful technique for designing the concrete elements. Right selection of concrete constituents and careful mixture proportion can provide a highly integrated concrete, which can substantially abate the process of corrosion initiation. More promising methods for protecting steel bars in concrete were found to exist. Several research studies showed the advantages of using anticorrosion agents, sacrificial anode by cathodic protection, and epoxy coating on the steel bars in civil engineering application. However, the cost of concrete construction is an important factor for executing infrastructure project and, hence, additional protection techniques can increase the cost. Hence, it is better to find a cost effective technique with the proper selection of concrete which can protect the rebar against corrosion $[1,2]$. Addition of mineral admixtures with inclusion of steel fibres causes significant improvement on the micostructural properties and can lead to refined pore structure. Moreover, the process of corrosion occurs due to poor cover concrete materials. This serves as an entry point of corrosion initiation and, hence, the process of corrosion being accelerated in a short period. However, the inclusion of steel is a major application of fibre reinforced concrete and finds potential merits for providing high quality construction without rebar and, hence, any costly treatment method cannot be suitable for surface treatment of steel fibres $[3,4]$. The process of corrosion in fibre reinforced concrete 
is phenomenal due to homogenized steel fibre distribution and, hence, more careful attention has to be provided for designing concrete constituents. In this direction, the cement replacements such as fly ash, ground granulated blast furnace slag, and silica fume were typically used in concrete construction to save cost [5-8]. The addition of such supplementary materials is found to be one choice for reducing the corrosion potential of steel fibre incorporated concrete mixtures. Many studies conducted in this direction have focused on rebar corrosion of reinforced concrete element in which different industrial waste materials had been incorporated to improve the pore properties of concrete $[9,10]$. This beneficial addition of binder materials showed an enhanced performance of corrosion process. In another study, the process of corrosion initiation was observed during its exposure to aggressive chloride environment and continues over longer period leading to aggressive corrosion process [11-13]. Studies also indicated that the high volume fly ash with steel fibre incorporated rebar concrete had shown a favorable reduction in the corrosion potential. The thickness of corrosion was identified in the corrosion process for different fly ash substituted concrete $[14,15]$. The rate of change of strain was measured using strain gauge principle in which the fly ash based fibre reinforced concrete showed lesser corrosion potential and type of mixes. Studies conducted in the past had shown that much focus is required to study the effect of corrosion in steel fibre incorporated concrete. Also, the accelerated corrosion process occurring in stressed concrete elements needs further investigation to understand the structural efficiency. The incorporation of binder materials such as slag in cement also needs to be carefully investigated.

1.1. Research Significance. The present research study evaluates the effects of ground granulated blast furnace slag and corrosion inhibitor on the process of corrosion in steel fibre reinforced concrete. The significance of filler binder materials (slag) for better improvement on the strength properties (such as compressive and flexural) of steel fibre concrete is studied. Enhanced interfacial characteristics and bonding stress between cement and the fibres are also investigated systematically.

\section{Experimental Investigations}

The details of concrete making materials used in the present study are as follows.

2.1. Cement. Ordinary Portland cement of grade 53 which had a specific gravity of 3.14 , fineness modulus 2.56 , consistency limits $32 \%$, initial setting time $165 \mathrm{~min}$, and final setting time of cement 255 min was used.

2.2. Aggregates Used. A crushed granite waste such as manufactured sand (M-sand) conforming to zone III as per IS 3831970 [16] was used as fine aggregate filler. The specific gravity value of M-sand was 2.45 and the loose bulk density values of $\mathrm{M}$-sand were $1600 \mathrm{~kg} / \mathrm{m}^{3}$. Crushed granite was used as coarse

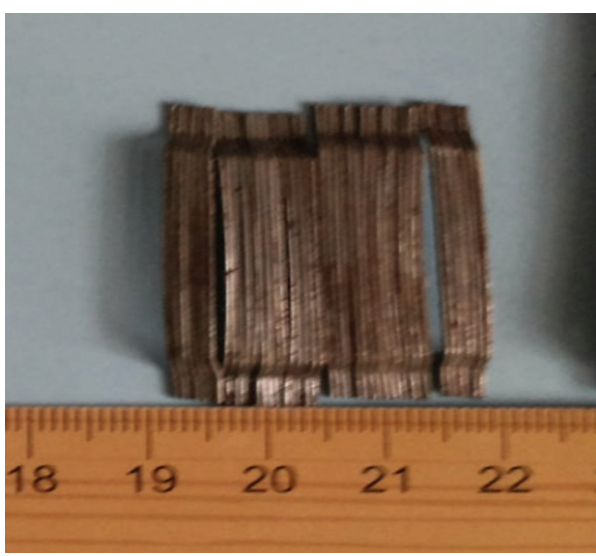

FIGURE 1: Glued steel fibres used in the study.

aggregate passing through $20 \mathrm{~mm}$ and $12 \mathrm{~mm}$ down having specific gravity of 2.64 and conforms to IS 383-1970.

2.3. GGBS. The physical properties of ground granulated blast furnace slag are as follows: specific gravity 3.43 and fineness modulus 3.35. The chemical properties are as follows: carbon (C) $0.24 \%$, manganese $(\mathrm{Mn}) 0.58 \%$, sulphur (S) $0.05 \%$, phosphorous $(\mathrm{P}) 0.06 \%$, free silica $6.10 \%$, and iron $(\mathrm{Fe})$ $92.97 \%$. Slag was replaced for cement at $20 \%, 40 \%$, and $60 \%$ by weight of binder.

2.4. Chemical Admixtures. In order to improve the workability properties of concrete and to avoid the harshness of the concrete at low water content, the addition of chemical admixtures was found to be essential. In the present study, a polycarboxylate ether based superplasticizer was used at an optimum dosage of $1.5 \%$ (by weight of cement). The mix water used for preparing concrete specimens was free from chlorides and sulphates. The study was also conducted with addition of anticorrosion inhibitors at $0.3 \%, 0.6 \%$, and $0.9 \%$ by weight of steel fibres.

2.5. Glued Steel Fibres. Glued steel fibres as shown in Figure 1 were used in the present study and the various properties of the material are as follows: length $60 \mathrm{~mm}$, diameter $0.75 \mathrm{~mm}$, aspect ratio 80 , and failure strain 3 to $5 \%$. The steel fibres were consisting of hooked ends to provide adequate end anchorages and bond strength in the concrete matrix. The glued steel fibres were bundled together using water soluble glue and, upon addition in concrete, the glue dissolved and dispersed homogenously in the concrete.

2.6. Concrete Mixture Proportions and Curing. A high strength concrete grade of M40 was designed as per IS 102622009 [17] and the detailed mixture proportions of concrete are given in Table 1 . The conventional concrete mix contained $100 \%$ manufactured sand (M-sand). The slag replacement level of $0 \%, 20 \%, 40 \%$, and $60 \%$ of cement was replaced. The desired workability of all concrete mixes was maintained using superplasticizer at a maximum dosage restricted up to 
TABLE 1: Various concrete mixture proportions used in the study.

\begin{tabular}{|c|c|c|c|c|c|c|c|c|c|c|}
\hline \multicolumn{2}{|c|}{ Mix ID w/b ratio } & \multirow{2}{*}{$\begin{array}{c}\text { Steel fibres }\left(V_{f}\right) \% \\
0\end{array}$} & \multirow{2}{*}{$\begin{array}{c}\text { Slag \% } \\
0\end{array}$} & \multirow{2}{*}{$\begin{array}{c}\text { Anticorrosion } \\
\text { inhibitors } \\
-\end{array}$} & \multirow{2}{*}{$\begin{array}{r}\text { SP \% } \\
1.5\end{array}$} & \multirow{2}{*}{$\begin{array}{c}\text { Cement } \\
449\end{array}$} & \multirow{2}{*}{$\begin{array}{c}\text { Slag } \\
0\end{array}$} & \multirow{2}{*}{$\begin{array}{l}\begin{array}{r}\text { Manufactured sand } \\
\mathrm{kg} / \mathrm{m}^{3}\end{array} \\
712\end{array}$} & \multirow{2}{*}{$\begin{array}{c}\text { Coarse aggregate } \\
1165\end{array}$} & \multirow{2}{*}{$\begin{array}{c}\text { Water } \\
135\end{array}$} \\
\hline GGC1 & 0.3 & & & & & & & & & \\
\hline GSF5 & 0.3 & 1.5 & 0 & - & 1.5 & 449 & 0 & 712 & 1165 & 135 \\
\hline GSF6 & 0.3 & 1.5 & 20 & - & 1.5 & 359 & 90 & 712 & 1165 & 135 \\
\hline GSF7 & 0.3 & 1.5 & 40 & - & 1.5 & 269 & 180 & 712 & 1165 & 135 \\
\hline GSF8 & 0.3 & 1.5 & 60 & - & 1.5 & 179 & 270 & 712 & 1165 & 135 \\
\hline $\mathrm{ACl}$ & 0.3 & 0 & 0 & 0.3 & 1.5 & 449 & 0 & 712 & 1165 & 135 \\
\hline AC2 & 0.3 & 0 & 0 & 0.6 & 1.5 & 449 & 0 & 712 & 1165 & 135 \\
\hline AC3 & 0.3 & 0 & 0 & 0.9 & 1.5 & 449 & 0 & 712 & 1165 & 135 \\
\hline
\end{tabular}

Note: $V_{f}$ : volume fraction, w/b: water to binder ratio, and SP: superplasticizers.

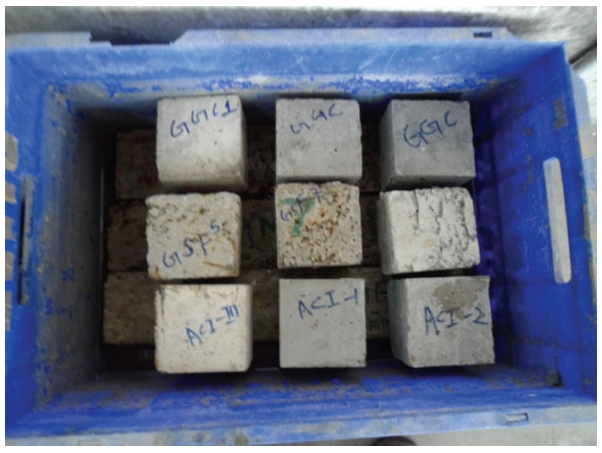

(a)

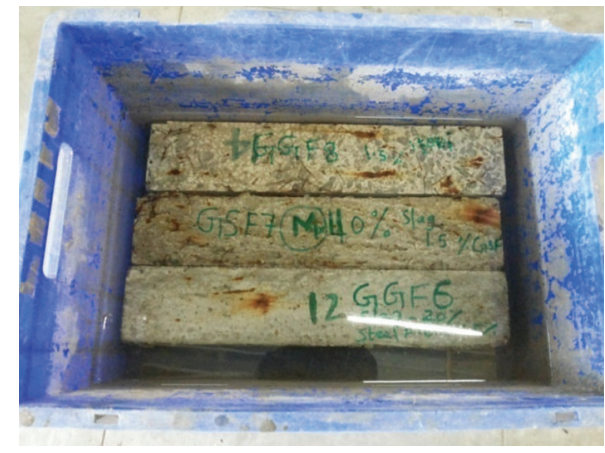

(b)

Figure 2: (a) Cube specimens cured in $\mathrm{NaCl}$ (3\%) solution. (b) Beam specimens cured in $\mathrm{NaCl}$ (3\%) solution.

$1.5 \%$ by weight of the binder. A horizontal pan mixer of 40 litres capacity was used for mixing the constituent material. Fresh concrete was casted in steel mould of size $100 \mathrm{~mm} \times$ $100 \mathrm{~mm}$ and beam mould of size of $100 \times 100 \times 500 \mathrm{~mm}$ for testing compressive and flexural strength properties, respectively. The specimens were remoulded after a day and cured in water tank at $35^{\circ} \pm 3^{\circ} \mathrm{C}$ for different curing days $(28,56,90$, and 180 days).

\subsection{Experimental Testing Procedure}

2.7.1. Accelerated Corrosion Process. Alternate wetting and drying cycles are done in order to accelerate the deterioration process. Similarly, the initial loading of concrete reflects the real-time situation wherein the concrete sustains dead load and results in opening up of stress induced microcracks. This actually provides the real quantification on the process of accelerated corrosion mechanism. Hence, the initial stress on the concrete can open up the microcracks and promulgates the water and chloride ions to penetrate the concrete specimens which can initiate the corrosion process of steel fibres. Initially, the specimens were cured for required 28 days and later stressed initially up to $40 \%$ and $60 \%$ of the ultimate load. Later, the specimens were subjected to alternate wetting and drying cycle for 28 days. This process is continued up to 6 months and subsequent testing was carried on the concrete specimens. After stressing, the specimens were immersed in chloride-free water (curing tank) for 1 day and later taken out for drying in hot air oven at $100^{\circ} \mathrm{C}$ for 1 day. This process is continued for 28 days till testing.

Similar methodology was also adopted for the other set of concrete specimens wherein the specimens were cured in sodium chloride solution prepared at $3 \%$ concentration and the snapshot of cubes and beams immersed in the solution are shown in Figures 2(a) and 2(b), respectively; similar cycles were also adopted to evaluate the strength degradation at different curing period till 6-month duration. Compressive and flexural strength loss for different time periods was recorded and systematically analyzed. Also, the thickness of steel fibres after corrosion was measured after 6 months for different concrete mixes subjected to accelerated corrosive environment.

2.7.2. Mechanical Testing. Compressive test was conducted in universal compressive testing machine of capacity $2000 \mathrm{kN}$ at a loading rate of $2.5 \mathrm{kN} / \mathrm{sec}$ (as shown in Figure 3) and flexural testing was carried out in a displacement control machine at $0.5 \mathrm{~mm} / \mathrm{minute}$ (as shown in Figure 4). Flexural testing was conducted as per standard specifications in a third point loading test setup. The loss in diameter of steel fibres due to corrosion was measured using a screw gauge. Initially, the rusted steel fibres were surface cleaned with an emery 


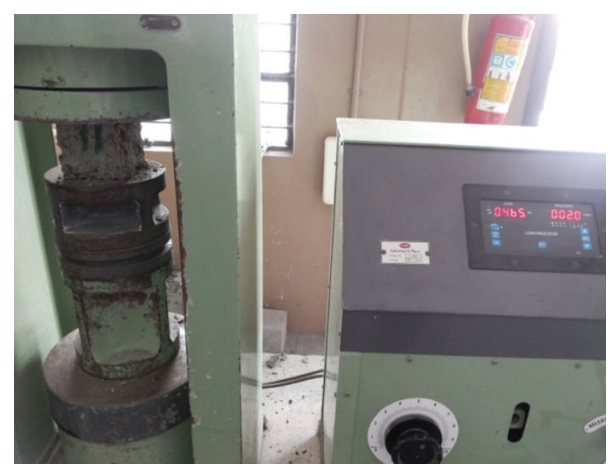

FIGURE 3: Initial stress applied to concrete specimens.

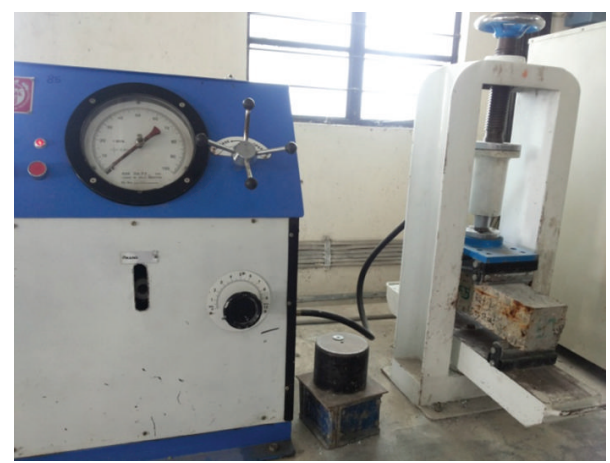

FIGURE 4: Snapshot of flexural test setup.

paper and then measured at different points along the length of fibre.

\section{Experimental Test Results and Discussions}

3.1. Effect of Corrosion due to Alternate Wetting and Drying Cycle. Test results of various steel fibre concrete specimens subjected to initial stress and cured in water and salt solution are provided in Figure 5. Initial stress applied on the specimens provides accelerated corrosion process and helps to assess the deterioration process in plain, slag, and corrosion inhibitor substituted concrete specimens. The experimental test results on the compressive properties of all slag substituted concrete mixes investigated showed a reasonable strength attainment above $40 \mathrm{~N} / \mathrm{mm}^{2}$ ( 28 days) which was higher than reference concrete. However, there was a significant increasing trend observed in the case of $40 \%$ slag concrete containing $1.5 \% V_{f}$ (volume fraction) of steel fibre reinforced concrete mixes. A high strength was recorded up to $49.80 \mathrm{~N} / \mathrm{mm}^{2}$ at 28 days for GSF7 concrete mix containing $40 \%$ slag with $1.5 \%\left(V_{f}\right)$ of steel fibres, which was $13.96 \%$ higher than that of control concrete (GGC1) as shown in Figure 5. The increase in diameter due to corrosion causes the subsequent increase on the compressive strength and the failure pattern as shown in Figure 6. It is understood that the strength increase was reported in steel fibre substituted concrete mixes due to better bonding of corroded fibres in the matrix. Also, the discrete fibre orientation and the

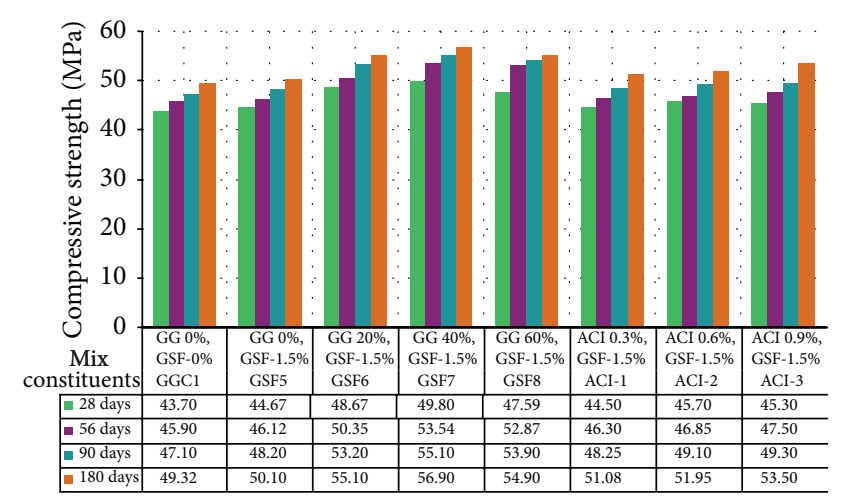

FIGURE 5: Compressive strength of concrete for alternate wetting and drying of concrete specimens in chloride-free water (stressed at $40 \%$ ultimate load).

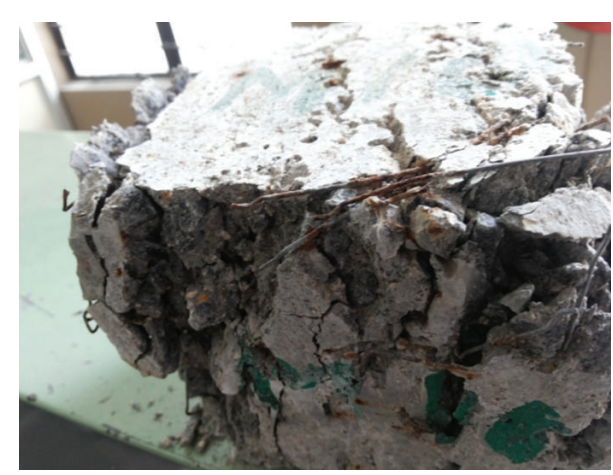

FIGURE 6: Failure pattern of corroded steel fibre concrete specimen.

corresponding increase in volume of corroded steel fibres had caused matrix interlocking. This eventually led to the increase in the strength of concrete and was reported at longer exposure up to 6 months of wetting and drying cycles. A similar trend was observed in the case of $20 \%$ slag with steel fibres at $1.5 \% V_{f}$ (volume fraction). Also, the addition of corrosion inhibitor provided a corresponding increase in strength as compared to that of slag substituted concrete mixes. It was clearly noticed that the addition of slag and corrosion inhibitor showed favorable reduction in the corrosion in $40 \%$ of stressed concrete specimens (as shown in Figure 7). It can be inferred from the test results that the improvement on the matrix properties of concrete systems occurred due to closer granular packing with the binder particles. This eventually contributed for a well-developed matrix system with low porosity and high densification of the mortar phase leading to improved compressive properties. With the addition of $20 \%$ slag, the compressive strength increase was observed and the optimum addition of $0.6 \%$ of anticorrosion inhibitor was also found to be showing improved performance (as shown in Figure 8). It is noted that the stressed concrete can be detrimental and, hence, addition of slag is favorable and the addition of admixture was found to reduce the corrosion process. In normal water, cured concrete specimens subjected to alternate wetting and drying had not showed considerable reduction in strength. Similarly, 


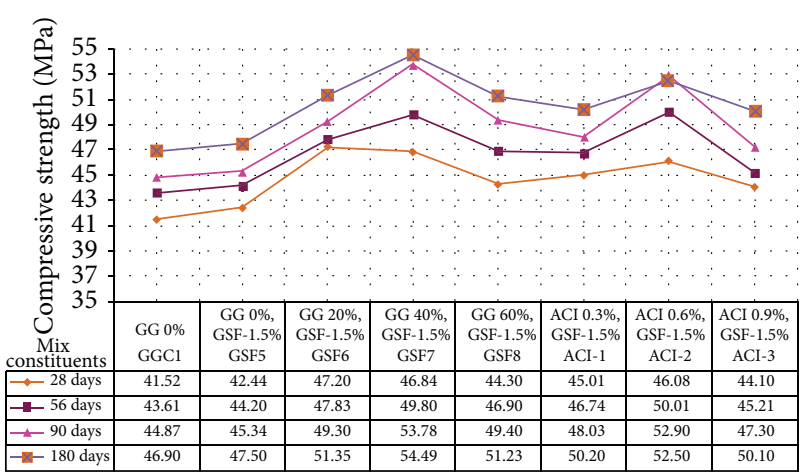

Figure 7: Compressive strength of concrete cured in $\mathrm{NaCl}(3 \%)$ solution for various mixes ( $40 \%$ stressed).

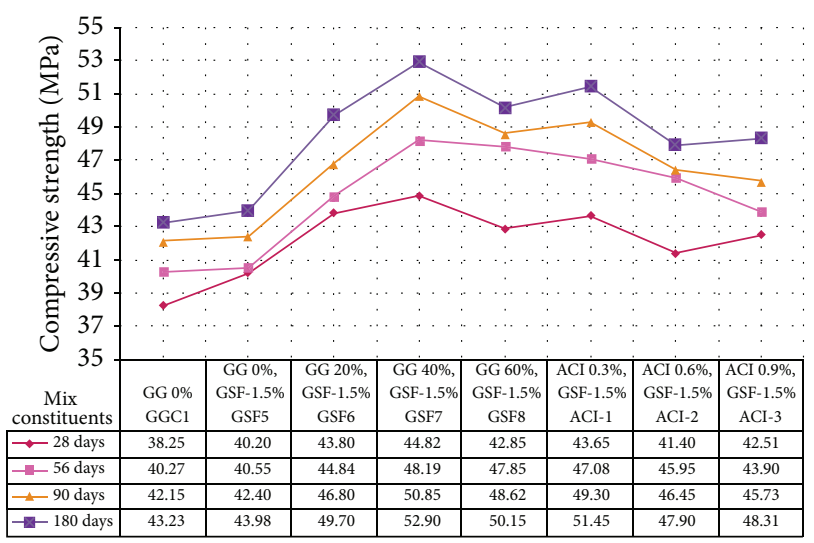

FIGURE 8: Compressive strength of concrete cured in $\mathrm{NaCl}(3 \%)$ solution for various concrete mixes (60\% stressed).

at higher stress (60\% of ultimate stress), the incorporation of high volume slag replacement up to $60 \%$ is needed and had shown promising improvements. It is understood that the corrosion of steel fibres had caused a great reduction in plain concrete compared to slang and corrosion inhibitor substituted concretes. However, the corrosion effects are accelerated in chloride environment due to faster deterioration.

3.2. Flexural Strength. The flexural strength test results for various steel fibre concretes are presented in Figure 9. During the initial loading up to $40 \%$ stress, the flexural strength was found to be unaffected in $40 \%$ slag substituted concrete. Similarly, the favorable improvement was noticed in anticorrosion inhibitors (ACI) concrete mixes. The wetting and drying of concrete specimens in normal water cured specimens showed a reduction in reference concrete and, with the addition of slag, it was better improved. Test results denoted clearly that the corrosion occurring in concrete results in effective bond developed between matrix and steel fibre interface. This actually provides enough pullout resistance and thereby increased the flexural load capacity. As noticed, the strength improvement was observed in flexural strength; on the other

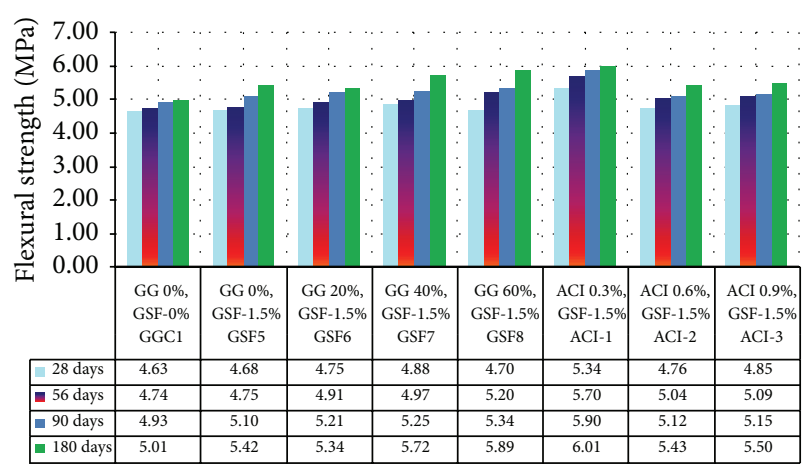

FIGURE 9: Flexural strength of concrete specimens for alternate wetting and drying cycles for various concrete mixes (subjected to $40 \%$ initial stress).

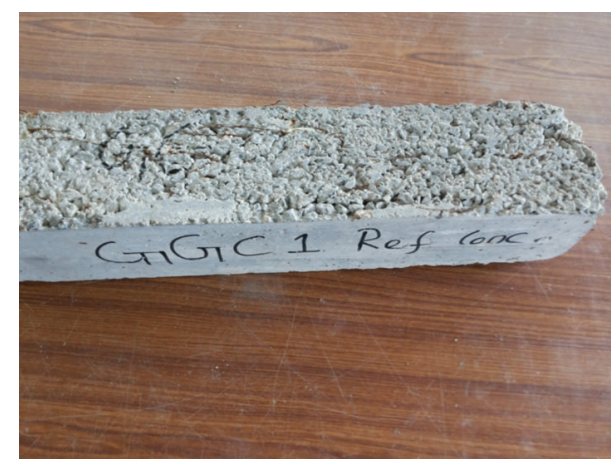

FIgURE 10: Plain concrete specimens exposed to sodium chloride solution (3\%).

hand, the strength reduction was noticed in compressive strength. It is understood that the accelerated corrosion causes intrusion of sodium chloride ions which had not caused enough deceleration on the strength gain. The effect of concrete deterioration is shown in Figure 10 and the corroded beam specimens tested in flexure are shown in Figure 11. The experimental trends shown in Figure 12 show flexural results of various steel fibre concretes subjected to initial stress and cured in salt solution. It was noted that the strength loss was not observed even though the severity of corrosion occurring in salt water was found to be higher. Surface erosion of plain concrete occurred in plain concrete compared to steel fibre concrete possibly due to leaching of calcium ions leaving roughened surface. From the results it was also noted that corrosion effects in steel fibre concrete were not reported in slag concrete and corrosion inhibitor added concrete. This subsequently showed higher strength gain compared to reference concrete without slag and corrosion inhibitor.

The effects of corrosion in different concrete mixes were analyzed after failure and the degree of corrosion occurring in concrete specimens were shown in Figure 13. The reduction in diameter of steel fibres showed the degree of corrosion and was represented in Figure 14. It can be easily seen in plain concrete mixes that the degree of corrosion in steel fibres was higher up to $52.00 \%$ (GSF5). With the incorporation 


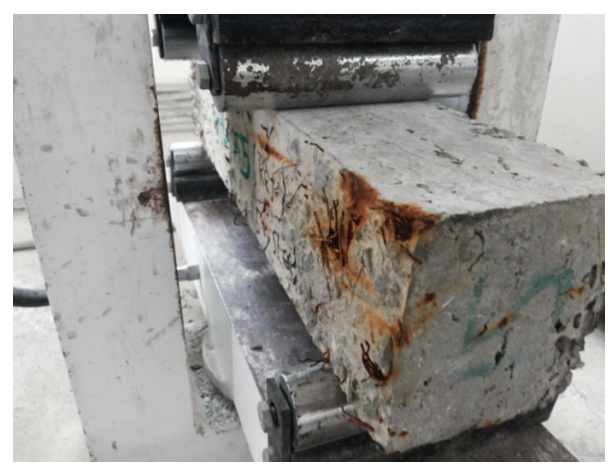

Figure 11: Flexural testing of corroded steel fibre concrete specimens.

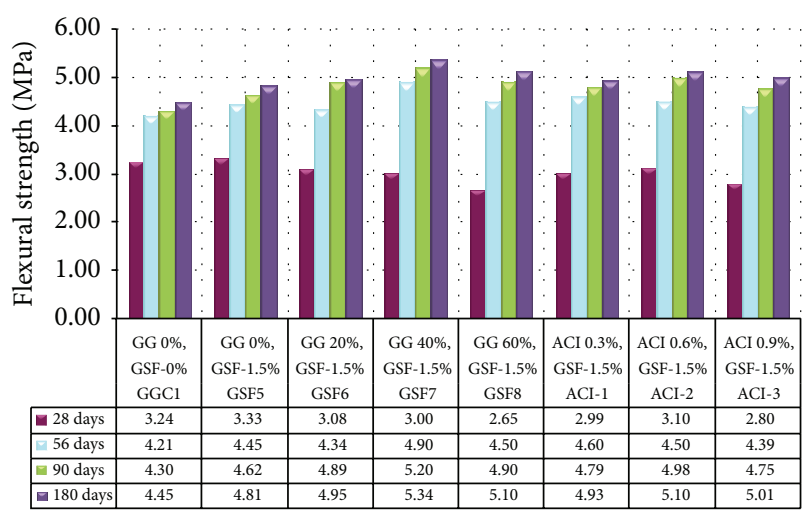

FIGURE 12: Flexural strength of concrete specimens cured in sodium chloride solution for various concrete mixes (subjected to $40 \%$ initial stress).

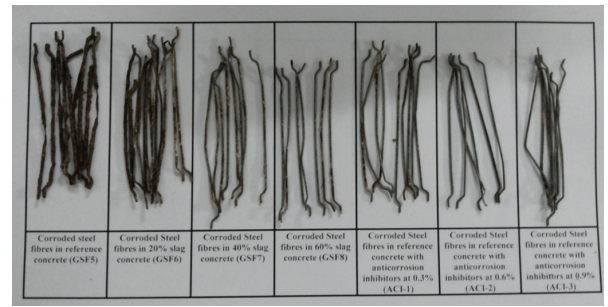

FIGURE 13: Snapshot of corroded steel fibres in different concrete mixes containing slag and corrosion inhibitor.

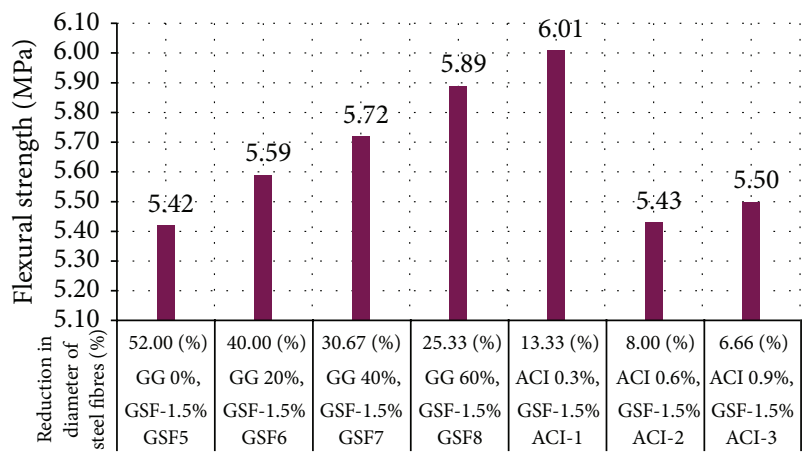

FIgURE 14: Variation of flexural strength with respect to \% of reduction in thickness of steel fibres.

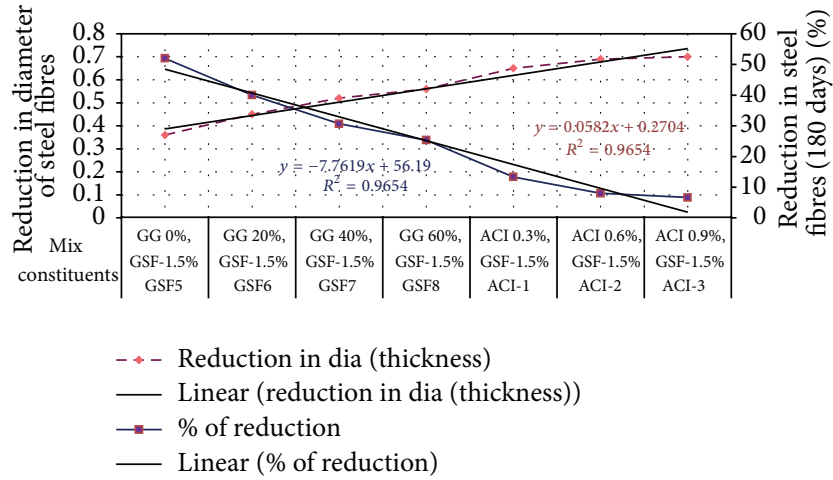

FIgURE 15: Variation of reduction in steel fibre diameter and the percentage reduction in steel fibre diameter for various concrete mixes.

of slag up to $60 \%$, the reduction of corrosion in steel fibres was found to be $25.33 \%$ (GSF8). Also, the corrosion potential was reduced significantly with the addition of corrosion inhibitor in plain steel fibre concrete and showed a reduction up to $6.66 \%$ (ACI-3). The reduction in diameter of various steel fibres in different concrete mixes showed the degree of corrosion occurring in concrete (as seen in Figure 15). This can possibly give the qualitative and quantitative assessment on the degree of corrosion occurring in steel fibre concrete specimens.

\section{Conclusions}

Based on the experimental investigation, the following conclusions are drawn within the limitations of the test results.

(i) Compressive properties of steel fibre concrete specimens were found to be affected when exposed to accelerated corrosion process due to rapid deterioration.

(ii) Alternate wetting and drying cycles of all plain steel fibre concrete mixes in normal water curing and salt curing showed rapid corrosion process after 28 days of curing period.

(iii) The influence of initial stress on the steel fibre concrete specimens reported faster initiation of corrosion process in steel fibres present in the concrete system. This provides a reliable estimate for predicting the corrosion potential in different concrete systems.

(iv) Compressive properties were found to be favourably improved in slag incorporated steel fibre concretes compared to plain steel fibre concretes.

(v) Compared to concrete specimens subjected to normal water curing, the specimens immersed in salt solution showed faster deterioration in terms of concrete surface deterioration as well as corrosion of steel fibres.

(vi) Strength increase was noticed in all steel fibre concrete specimens incorporating slag and corrosion 
inhibitors. This could be possibly due to improved micostructural properties of slag concrete and the corrosion inhibitors possibly reduced the intensity of steel fibre corrosion.

(vii) Compressive strength was found to be higher $(54.49 \mathrm{MPa})$ in $40 \%$ slag substituted concretes as well as with the addition of corrosion inhibitor at $0.6 \%$ showing $52.50 \mathrm{MPa}$.

(viii) Flexural strength results also showed improvement with the slag substitution $(60 \%)$ as well as corrosion inhibitor $(0.9 \%)$ added steel fibre concrete mixes. A maximum flexural strength of $5.89 \mathrm{Mpa}$ was noticed in slag substituted concrete mixes subjected to severe wetting and drying cycles accompanied with initial stress up to $40 \%$.

(ix) The intensity of corrosion was measured with the reduction of steel fibre diameter and can predict the degree of corrosion measured in terms of percentage of corrosion potential. A maximum reduction in corrosion percentage up to $25.33 \%$ and $6.67 \%$ was noticed in slag and corrosion inhibitor substituted concrete mixes, respectively.

(x) Corrosion potential was found to be reduced in the case of slag substituted steel fibre concrete mixes up to a maximum of $25.33 \%$.

\section{Conflict of Interests}

The authors declare that there is no conflict of interests regarding the publication of this paper.

\section{References}

[1] M. Otieno, H. Beushausen, and M. Alexander, "Effect of chemical composition of slag on chloride penetration resistance of concrete," Cement and Concrete Composites, vol. 46, pp. 56-64, 2014.

[2] S. Teng, T. Y. D. Lim, and B. Sabet Divsholi, "Durability and mechanical properties of high strength concrete incorporating ultra fine ground granulated blast-furnace slag," Construction and Building Materials, vol. 40, pp. 875-881, 2013.

[3] M. O'Connell, C. McNally, and M. G. Richardson, "Performance of concrete incorporating GGBS in aggressive wastewater environments," Construction and Building Materials, vol. 27, no. 1, pp. 368-374, 2012.

[4] P. Pipilikaki, M. Katsioti, and J. L. Gallias, "Performance of limestone cement mortars in a high sulfates environment," Construction and Building Materials, vol. 23, no. 2, pp. 1042-1049, 2009.

[5] C. D. Atiş and O. Karahan, "Properties of steel fiber reinforced fly ash concrete," Construction and Building Materials, vol. 23, no. 1, pp. 392-399, 2009.

[6] S. Pavía and E. Condren, "Study of the durability of OPC versus GGBS concrete on exposure to silage effluent," Journal of Materials in Civil Engineering, vol. 20, no. 4, pp. 313-320, 2008.

[7] A. Oner and S. Akyuz, "An experimental study on optimum usage of GGBS for the compressive strength of concrete," Cement and Concrete Composites, vol. 29, no. 6, pp. 505-514, 2007.
[8] Building Research Establishment, BRE Special Digest 1: Concrete in Aggressive Ground. Part 1: Assessing the Aggressive Chemical Environment, BRE, 2nd edition, 2003.

[9] ACI Committee, "Protection of metals in concrete against corrosion," ACI 222R-01, American concrete Institute, Farmington Hills, Mich, USA, 2001.

[10] S. U. Al-Dulaijan, M. Maslehuddin, M. M. Al-Zahrani, A. M. Sharif, M. Shameem, and M. Ibrahim, "Sulfate resistance of plain and blended cements exposed to varying concentrations of sodium sulfate," Cement and Concrete Composites, vol. 25, no. 4-5, pp. 429-437, 2003.

[11] G. J. Osborne, "Durability of Portland blast-furnace slag cement concrete," Cement and Concrete Composites, vol. 21, no. 1, pp. 1121, 1999.

[12] R. S. Gollop and H. F. W. Taylor, "Microstructural and microanalytical studies of sulfate attack. V. Comparison of different slag blends," Cement and Concrete Research, vol. 26, no. 7, pp. 1029-1044, 1996.

[13] V. Pavlík and S. Unčík, "The rate of corrosion of hardened cement pastes and mortars with additive of silica fume in acids," Cement and Concrete Research, vol. 27, no. 11, pp. 1731-1745, 1997.

[14] N. de Belie, H. J. Verselder, B. de Blaere, D. van Nieuwenburg, and R. Verschoore, "Influence of the cement type on the resistance of concrete to feed acids," Cement and Concrete Research, vol. 26, no. 11, pp. 1717-1725, 1996.

[15] E. K. Attiogbe and S. H. Rizkalla, "Response of concrete to sulfuric acid attack," ACI Materials Journal, vol. 85, no. 6, pp. 481-488, 1988.

[16] BIS (Bureau of Indian Standards), IS 383: Specification for Coarse and Finer Aggregates from Natural Sources for Concrete, Bureau of Indian Standards, New Delhi, India, 1970.

[17] BIS (Bureau of Indian Standards), IS 10262-2009: Concrete Mix Proportioning-Guidelines, New Delhi, India, 2009. 

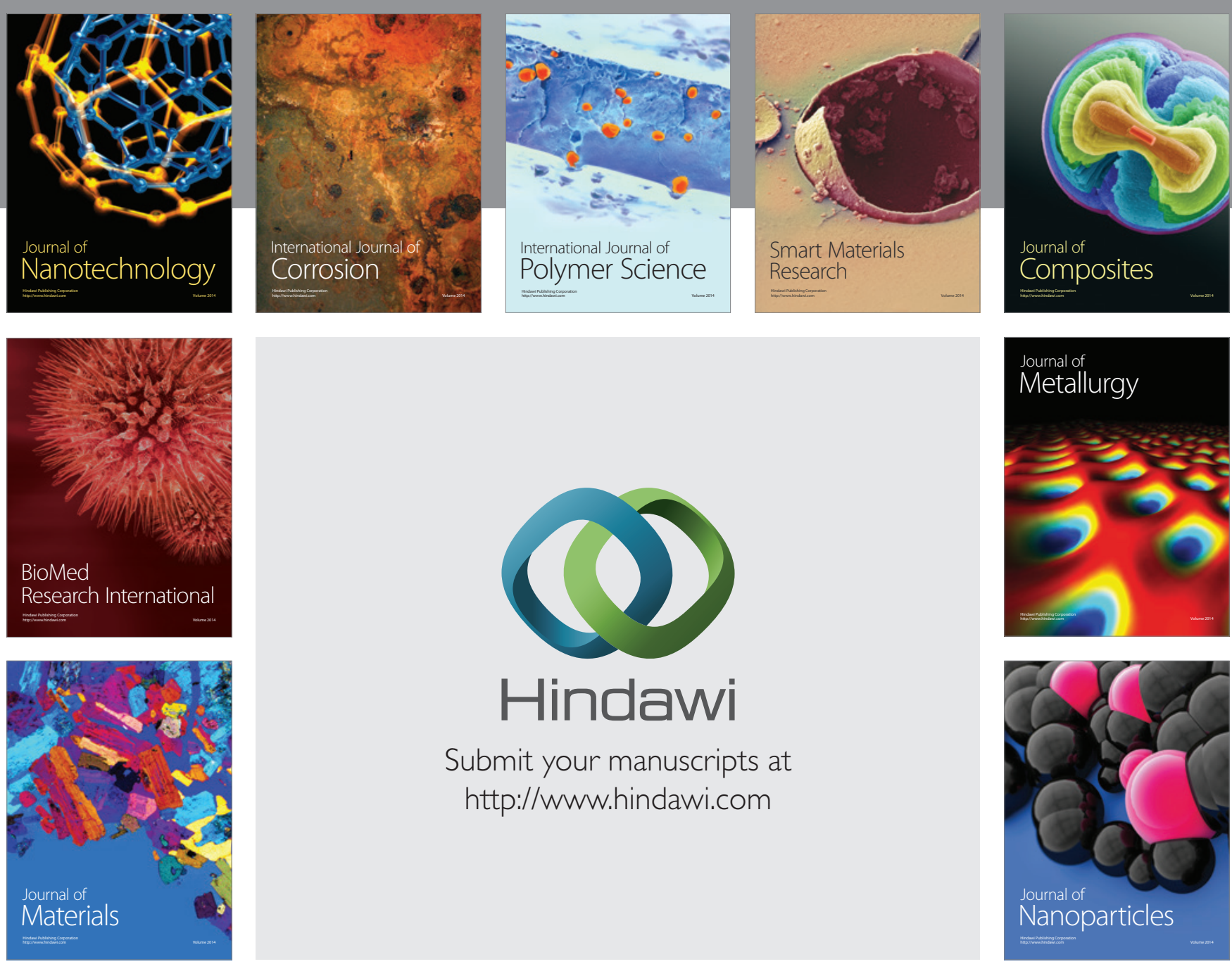

Submit your manuscripts at http://www.hindawi.com
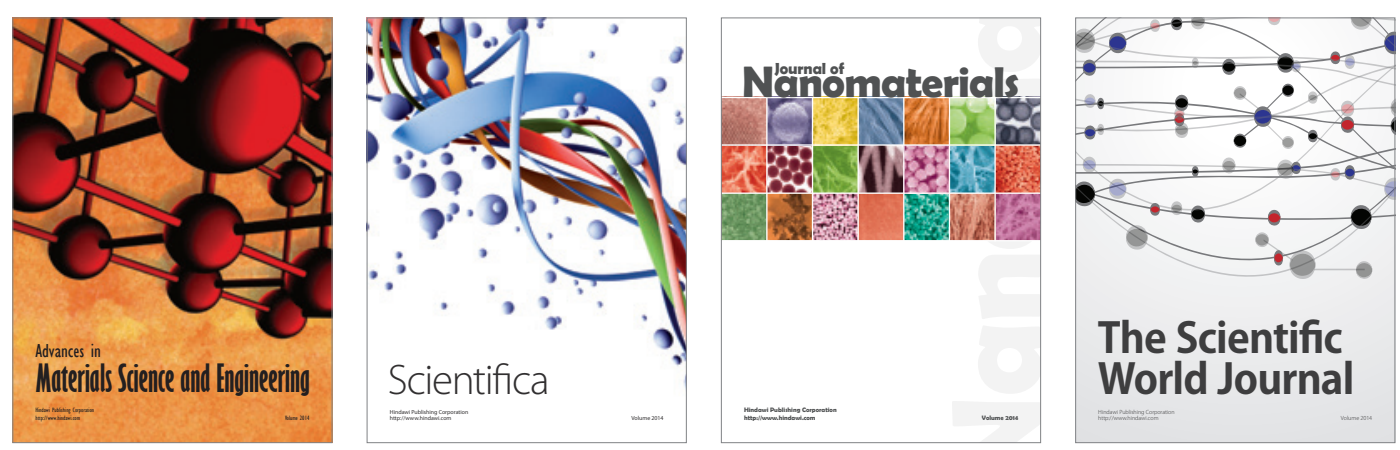

\section{The Scientific World Journal}
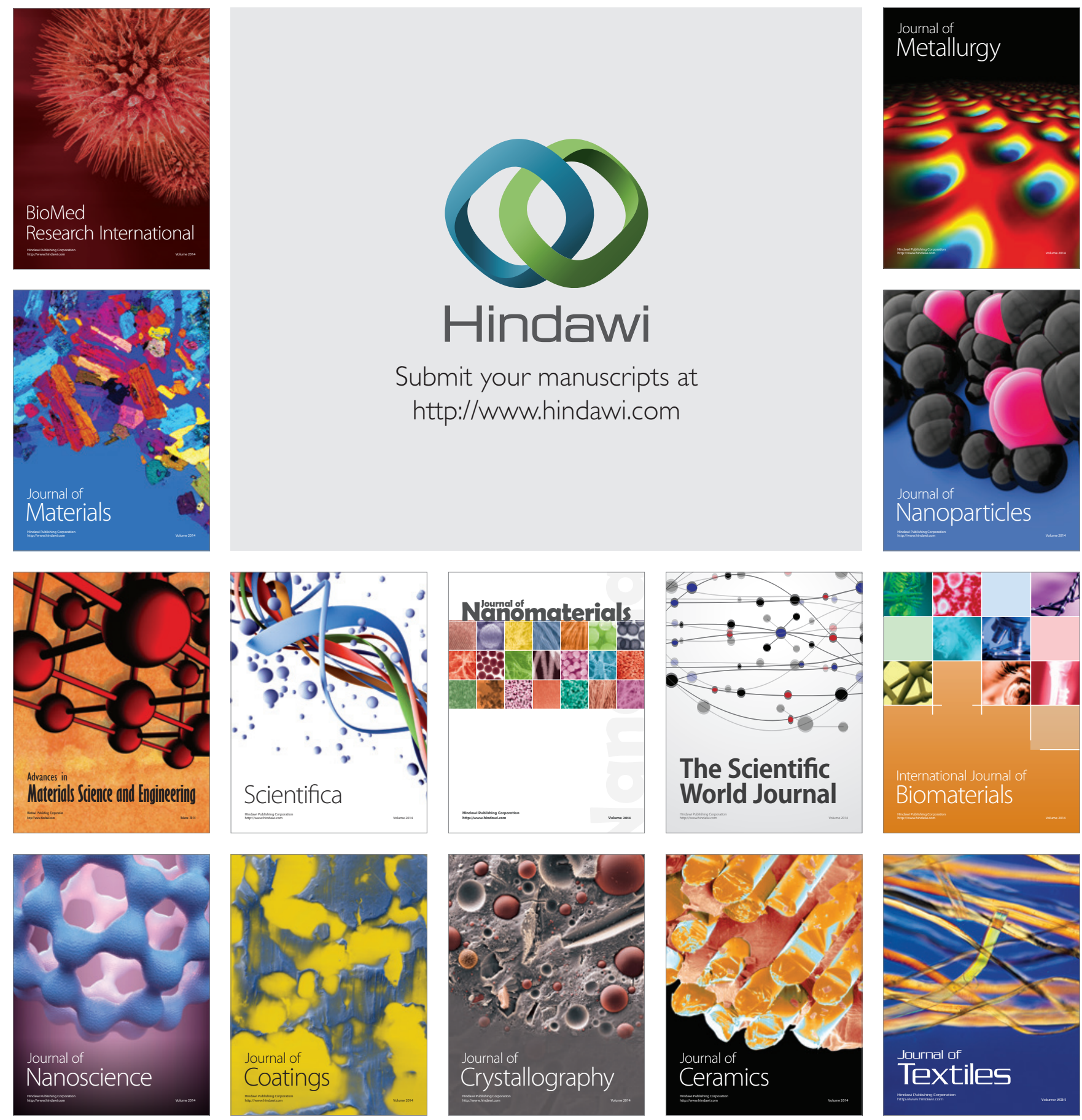